\title{
Breast Cancer pTis TNM Finding v6 and v7
}

National Cancer Institute

\section{Source}

National Cancer Institute. Breast Cancer pT is TNM Finding v6 and v7. NCI Thesaurus.

Code C48974.

Breast cancer with a finding of carcinoma in situ. (from AJCC 6th and 7th Eds.) 